Article

\title{
What Can the New Vatican Spokesman Do in the Era of Abuse Crisis?
}

\author{
Tereza Zavadilová
}

check for updates

Citation: Zavadilová, Tereza. 2021. What Can the New Vatican Spokesman Do in the Era of Abuse Crisis? Journalism and Media 2: 440-453. https://doi.org/10.3390/ journalmedia2030026

\section{Academic Editor:}

Andreu Casero-Ripollés

Received: 11 May 2021

Accepted: 28 June 2021

Published: 21 July 2021

Publisher's Note: MDPI stays neutral with regard to jurisdictional claims in published maps and institutional affiliations.

Copyright: (C) 2021 by the author. Licensee MDPI, Basel, Switzerland. This article is an open access article distributed under the terms and conditions of the Creative Commons Attribution (CC BY) license (https:// creativecommons.org/licenses/by/ $4.0 /)$.
Institute of Communication Studies and Journalism, Faculty of Social Sciences, Charles University, 11000 Prague, Czech Republic; tereza.zavadilova@fsv.cuni.cz

\begin{abstract}
The Catholic Church (Further referred to as "Church" for shortening) has been facing a number of scandals regarding its priests and religious figures for several decades. Therefore, effective measures, considering legal or pastoral changes, and a working communication strategy are necessary to deal with the sad facts and to regain credibility through means of accountability, transparency, and solidarity. The expectations of what the official Vatican media-which has been undergoing multi-layer reform since 2015-is for are changing quickly and dramatically in the era of abuse crisis, possibly even having a wicked character. Among the initial commitments of the curial Dicastery for Communication included the criteria of paying "special attention to situations of hardship, poverty and difficulty". We shall necessarily ask whether the employees and servants in Catholic Church communication are aware of all the contemporary risks and possible consequences of being resistant to it. The goal of this contribution is to inquire if and how the character of Vatican communication changed in this direction and whether it reacted to the critique and to the doubts made on the level of credibility and accountability. The time limitation is the second half of 2019-since the appointment of the new Vatican spokesman Matteo Bruni in July 2019 to November 2019. The article takes into account the official Vatican News website data source and asks how flexibly Bruni responded to the critical situation.
\end{abstract}

Keywords: Catholic Church; Vatican; media reform; Dicastery for Communication; Pope Francis; clergy sexual abuse

\section{Introduction}

Uncertainty influences the global media today because of the reality of fake news, disinformation or hate speech, and the fact that almost everybody can create a visible media channel distributing ideas to their surroundings, independent of their trustworthiness. Recipients are often confronted with the concept of post-truth and the decline of rationality in favour of subjectivity and emotiveness (D'Ancona 2017). Hence, the challenge to creating an atmosphere of trust and credibility stands in front of the professional secular media as well as the religious media.

The contemporary moment of abuse crisis is uncertain, especially for the Catholic faithful. As the Catholic Church undergoes a deep crisis of credibility connected with a long-lasting abuse of power, conscience, and the sexual abuse of minors and vulnerable adults, the necessary part of its public role as well as its core teaching is to speak openly and honestly about what is happening. The theme of the official media communication of the Catholic Church became highly socially relevant in 2018 when many global abuse scandals from the 20th century again came to light as a theme of the secular media and of public debate in general. The world still waits for a clear and decisive reaction from the authorities. With the appointment of Pope Francis in 2013, many reforms progressed gradually. The reform of the Vatican media branch was his priority and should serve as the "pattern" for the reform of the whole Curia. Therefore, it is necessary to make an inquiry into the possible relation between the Vatican media reform and the willingness to communicate the truthopenly regarding the cases of abuse in Vatican media. 


\section{Vatican Media Reform}

Broadly speaking, the Curia is the sophisticated administrative and juridical organ that coordinates the Catholic Church; apart from the Secretary of State and Secretary of Economy, it contains nine congregations, five pontifical councils, six pontifical commissions, tribunals, academies, and other councils, departments, and dicasteries (La Curia Romana 2019). Although the pope has absolute executive, legislative, and juridical power on the level of the Vatican, the Church is managed by the Curia. Nevertheless, "[d]espite its outsized image as a global religious colossus, Catholicism as its core is a remarkably small enterprise" (Allen and Martín 2017, p. 21). More than 5000 people work in the Vatican, which translates to a "ratio of one bureaucrat for every 231,000 Catholics in the world" (Allen and Martín 2017, p. 21).

The inseparable part of the Roman Curia is from 2015, as is the Secretariat for Communication (Pope Francis 2015), later renamed "dicastery" (Pope Francis 2018), which is in the context of previous facts rather than an exception, for it is the largest Vatican department in terms of personnel, with more than 600 members of staff from several countries (it incorporated the Vatican Radio, TV, Publishing house, Photobank, Press Office, etc.). The official department of Vatican media, which has already been made a subject of academic inquiries (Gesiak 2017; Diez Bosch 2018), identifies its purpose: "not just to inform", but instead to "offer a key to interpret news and information in the light of the Gospel" and to "respond ever better to the needs of the mission of the Church" in contemporary culture and "communicate the Gospel of mercy to all peoples" according to different cultures (About Us 2019). The guiding criteria of the newscast service Vatican News are those of being "apostolic and missionary" or paying "special attention to situations of hardship, poverty, and difficulty" (Pope Francis 2017).

Into this list of statutes may also neatly fit the coping with any form of abuse in the Catholic Church. The challenges posed by the abuse crisis, which started in 2018 with scandals of Chilean bishops, continued with the trial of Australian cardinal George Pell or French cardinal Philippe Barbarin, the historical laicization of American cardinal Theodor McCarrick, the context of the so-called Synodal Way in Germany, or the most recent progress in the investigation into Central and Eastern Europe (i.e., Poland, Czechia)-a kind of warning signal of the possible risk sassociated with not communicating openly. According to what was said, this might call into question the whole accountability of Pope Francis and his closest team.

Nevertheless, we are witnessing certain progress in communicating several topics, including abuse through the means of Catholic media. Within the Church, Vatican media has undergone a general, five-year-long reform process including digital transformationnamely, convergence, multilingualism, and multiculturalism-creating a multimedia service with multichannel and multidevice usage, as observed in the outlet of its several branches. Vatican radio, TV, the website Vatican News, the Publishing House, and Photographic Agency were incorporated into the Dicastery for Communication. Interestingly, only the Press Office-continuously collaborating with the dicastery-still belongs to the agenda of the Secretary of State.

As one of the biggest novelties, the online service Vatican News has been connecting the multilingual, multicultural, multichannel, and multimedia spheres since 2016, now in 38 language versions. More than three years later, the first possible results of the content reform have become visible, such as the frequent presentation of the sexual abuse cases in 2018, when the crisis reached its peak and even became "interwoven with a lot of other topics" (López 2019, p. 6).

Indeed, high expectations, such as fostering greater coordination and economies of scale, were positioned at the beginning of Secretariat's history under the initial leadership of Mons. Dario Vigano. "In general, the Vatican appears to be moving in the direction of greater transparency and cooperation with journalists, and that cannot help but seem like good news in terms of getting the story right" (Allen and Martín 2017, p. 3). Nevertheless, 
Mons. Viganò resigned in March 2018 after the Lettergate scandal because of the alleged manipulation of the photo of a letter of Pope Emeritus Benedict XVI (Vatican News 2018b).

In this context, the Vatican media remain the representative of today's media outlet once strongly influenced by the fact of authoritarian or hegemonic Church tradition, but slowly and critically evaluating its stance towards uncertainty-partly by integrating lay people into communications. We have witnessed many personal changes in the media dicastery. Since 2018, two skilled lay journalists have been leading it—Paolo Ruffini as its prefect (Vatican News 2018a) and Andrea Tornielli as the editorial chief of the dicastery (Bordoni 2018). The employment of such specialists was not very common in the Vatican until that time. In addition, Alessandro Gisotti was doing a good job in the surprisingly announced position of "ad interim" spokesman, which meant that he had known in advance that his position (taken after the accidental resignation of the previous spokesman Greg Burke on 30 December 2018) was only temporary (Ibid.). He served for 7 months, filled with a number of affairs of clerics (Zanchetta, Apostolic Nuncio to France, Bransfield, etc.), the important Vatican summit "The Protection of Minors in the Church" in February 2019, and eight papal trips, five of which were overseas. "Objectively, [this has been] the most intense semester of the pontificate," he confessed later (Altieri 2019).

On 22 July 2019, Pope Francis appointed another layman, British-born linguist Matteo Bruni, as the new director of the Holy See Press Office (spokesman) instead of Gisotti. Bruni had already worked in the Vatican communications for over 10 years (coordinating the accreditation section when organizing journalists accompanying popes on foreign trips) and supposedly had good insight into this type of media. He graduated from La Sapienza University in Rome, where he had studied languages and literature (he is fluent in Italian, English, Spanish, and French). He was also interested in humanitarian cooperation and programs in support of elderly people. Bruni is married and has a daughter (San Martín 2019). Since 1966, all the directors of the Holy See Press Office have usually had some experience in journalism, both laymen and clerics. In what follows, we will examine how Matteo Bruni led the direction of the Press Office in that unsettling time.

\section{Historical View of the Relations between Catholic Church and Media}

The original purpose stimulating the origins of the Church was generally to preach the Gospel (Mark 16, 15). In other words, Christianity is fundamentally a "communicative event" (Spadaro 2014, p. 7). The theology teaches about the inherent connection between communion (or fellowship) and communication. In other words," communion in the Church is born from the auto-communication of God with humankind"; thus, theology is not any "thing" to communicate. Rather, communication is the central content of theology, and theology is itself a communicative event (Scharer and Hilberath 2008, p. 13). For this reason, media are not simply external to religion, but inherent to it as a condition.

For a prevailing time, since the Catholic Church gained its primacy in 313, its approach towards media was strictly hegemonical and led by the conviction that those who are situated hierarchically high should decide what is worth communicating and what is not. Later, included among the Church's dominant medieval communication techniques were homilies, biblical exegesis, and letters, but also official statements spreading down through the hierarchical organization and richly using metaphors, symbols, and biblical passages. The main topics of communication then were Church reforms and aims toward the independence of clerical power, but also inner crises and conflicts (especially the fight for investiture or the problem of simony) and, naturally, missions and crusades (Althoff et al. 2018). Apart from the prominent scholars employed in medieval universities, there was typically no possibility for folk lay people to participate in this communication. They were commonly taught the biblical truths via schematic images in churches.

The invention of the enormous importance for Church communication as well as the democratization of access to information took place in the 1440s with Gutenberg's book printing machine. The success of the Protestant movement and of Martin Luther's mission was made possible thanks to the effective dissemination of content. Luther was 
the first person ever capable of publishing more than 100,000 prints (Petráček 2013, p. 39). Therefore, the authors describe that period as the "first media war" (Václavík 2010, p. 322). The subsequent counter-reformative Catholic Council in Trento (1545-1563), also known as Trident Council, is considered the first council of the print age. It is not without interest for the theme of this paper that the council's teaching, except for the vision of how to cope with Reformation, came with the novelty of the individual confession (Borg 2015, p. 14), which is considered as supporting the systematic phenomenon in the Church. This authoritative approach towards media was even strengthened by the First Vatican Council in 1869-1870 (Pastor Aeternus 1870), stressing the hierarchy in its ecclesiology.

When we continue into the 20th century, the Catholic Church was the key investigator of the theological, pastoral, and moral implications of the media. In the period of 1936-2008, two encyclicals, two pastoral instructions, one conciliar decree, two major sets of pastoral guidelines, forty-two annual addresses, and at least ten minor documents on the topic of media were published, which is altogether "more than 175,000 words" (Caccamo 2008, p. 391). From the originally hostile approach of Pope Pius X (1907, see par. 50) or of Pius XI (1936), there emerged a positive consciousness of how the Vatican could employ media effectively.

The Pontifical Commission for Social Communication (PCSC) was established in 1948 by Pope Pius XI (later renamed to Council) to shape the Catholic social communication teaching (A brief outline and history of the PCSC 2019). The term media communication was not yet used at that time. Its role was not to "package and market a Jesus-technique for communications", but "attempting to sketch an ecclesiology for the cybernetic era" (Kappeler 2006, p. 135).

The contemporary media shape is concerned with the culmination of the reforms already introduced in the Second Vatican Council (1962-1965), which published a media decree (Inter Mirifica 1963), but also with the progress of the subsequent documents, papal letters and messages, encyclicals, and exhortations. Academic research affirms that these reforms were identified mainly with "reforming the Church's method of communication" (Kappeler 2006, p. 39), "ecclesial democratisation", and "recognition of the laymen's role-capacity" (Kappeler 2006, p. 45).

Indeed, many questions concerning the way of the Church's communication with the world were raised by the massive technological progress and emerging digital media. John Paul II — the media pope - had already predicted the coming of "new culture, new language, new techniques and new psychology" (John Paul II 1990), recognizing that media were able to change the world not by their means but because of the communicated content. Later, he released his last apostolic letter (John Paul II 2005), where he clearly appreciated media as more than good public relations for the Church, but instead as the instruments of social communication, formation of the human person, and promotion of the common good and solidarity, which all may be reached by constructive dialogue. According to the document, the Church has the need and the right to make its activities known, but together should guarantee an adequate confidentiality. This apostolic letter written for the situation of the 21st century shall be considered as a logical continuation of the previous pastoral instructions (Communio et Progressio 1971; Aetatis Novae 1992), although it has greater magisterial binding.

In the 3rd millennium, digitalisation changed the communication of religions in general (Campbell 2014). The historically hierarchical relationships between "leaders" and "followers" in the producing and consuming of media were not as sustainable as before. Broadly speaking, we can argue that today, the roles of Catholic media production differ among the evangelization purpose, self-organisational purpose, and the critical Catholic journalism, which polemizes with the "official" course. Starting from the bottomup, we can name the Catholic blogosphere and life on social media (Facebook, Twitter, Instagram, YouTube, etc.); and then, following the hierarchical relationships, the parish magazines and websites, such as media on the diocese and archdiocese levels; and finally, media established in the Vatican as the centre of the universal Church. 
In this context, the big theme of Pope Benedict XVI was that latent "Christian roots" prevailed, but the sense of what the faith really is to be is deeply missing in the contemporary world with its unbridled consumerism and idolatry. Therefore, he questioned not the technology itself but the power it has been given by humanity. Contrary to the Pope's intention then, the media stressed the common stereotypical assumption that "religion and science are always at conflict with one another" since the framing of the Galileo trial from the 17th century (Campbell 2010, p. 4).

It was demanding for Benedict XVI to communicate in the digital era in a two-way mode. Nevertheless, as a significant step in the progress of two-way communication, the first papal tweet ever made by Benedict XVI appeared in December 2012 through the account @Pontifex, soon before his surprising resignation in 2013. Pope Benedict XVI even labelled social networks "portals of truth and faith" or "new spaces for evangelization" (Benedict XVI 2013).

His successor Pope Francis is without a doubt a great communicator, and the character of today's Catholic media is, to a large extent, shaped by his personality, which, in some occasions, even verges on the "cult of authenticity" (Lundgren 2017, p. 308). This means that the media are not reflecting all his words and actions critically but concentrate on those which suit the media-built narrative of Francis. In Francis's favour is the fact that he "believes in the importance of Vatican diplomacy" (in a broad sense) much more than Benedict XVI ever did (Giovagnoli 2019, p. 459). There were even articles published comparing the communication styles of these two popes (Javier Pérez-Latre 2019). Although the number of followers, retweets, or likes on social sites is not necessarily in correlation with the ability of a leader to influence, it is still the best possible manner for inquiring into that area (Cha et al. 2010). Furthermore, Francis is even referred by one author as "one of the most influential leaders of our time" (Palakeel 2019, p. 248). The fact that popes since Benedict use social sites to communicate with a worldwide audience is not necessarily limited to Catholic recipients. According to one survey, some $40 \%$ of Francis's tweets were for everybody, and Catholics as the target audience landed in the last position (Narbona 2016).

The Twitter activity of popes is also an important manifestation of theological truththeir continuity as "Successors of Peter" in the guiding of the Church. They all embody a figure transmitted over time (Code of Canon Law 1983). This happens frequently in the media space, where Francis tries to act as "charismatic" or "extraordinary"; as being "treated as endowed with supernatural, superhuman, or at least specifically exceptional powers or qualities" (Weber 1978, pp. 241-42); or rather as a transformative leader than simply a manager of the institution (Bass and Avolio 1994; Mintzberg 2010; Northouse 2013). He not only has the personal qualities but also inspires the lives of people and acts as the "transcendent leader" (Narbona 2016, p. 92). To put it clearly, he is of course both manager (orders the task, organises the personnel, and deals with the problems) and leader (has a vision, seeks unity and cooperation, and adds inspiration).

\section{Clergy Sexual Abuse as Communication Threat but also Opportunity}

The abuse of power in all its consequences is considered a lamentable problem in allhuman societies-including the Catholic Church. Although the abuse of power and conscience (leading in some cases to the sexual abuse of minors) is often superficially labelled as an issue of the last 60 years only, we have plenty of notions about its risks in updated Church documents (i.e., Catechism of Catholic Church 1993, par. 2389; Code of Canon Law 1983, can. 84, can 277, par. 1-2, can. 1395). Originally, the Code even stipulated that "Clerics committing sexual sins" and "those who sexually abuse boys" are threatened with "irrevocable exclusion" (can. 18 and can. 71), which meant that they could not receive communion even at the time of death.

The abuse rooted in the mishandled clerical authority is noticed even in the early Christian literature (Didache 96, par. 2; see also Sipe 1995, p. 10). Even the Elvira council in 305-6 was occupied with the purpose of establishing Canons dealing with sexual sins 
(Farrell 2009). This means that the Church had already been aware of the devastating effects that sexual abuse has in any community and ordained the punishments for such behaviour. Although there is not enough documented complete evidence about the cases inhistory, we can presuppose that there was a massive number of them.

Apart from the most famous work of the Spotlight investigative team (Carroll and Rezendes 2002; Boston Globe 2002), there was also older literature issued (Podles 2008; Amundson et al. 1993; Burkett and Bruni 1993; etc.), not necessarily limited to the Church environment, explaining the changing concepts of childhood and victimization in historyand telling the sad stories with concrete experiences, warning against cover-ups and injustice. Hence, in the literature, there is alsoa confession of the strengthening of one's faith (Berry 2002).

The opinions on the crisis itself as well as on its result and preferred handling are strongly polarized, especially when we consider the fact of celibacy. Celibacy was ordered in 1139 (Second Lateran Council, can. 6, 7) and originally was meant to help to serve with the "undivided heart" in the lifestyle of purity and controlling one's own desires, thus resulting in complete devotion to God, free from ambivalence, a living symbol of the universality and meaning of divine love (John Paul II 1992, p. 29). At the beginning of the crisis, there was the conviction that matters were out of hand and rather random due to individually mishandled clerical celibacy among exclusively male clergy, suggesting the prevalence of homosexuality among them or the generally too strict Catholic teaching on human sexuality. On the other hand, authors critical to this approach argue that there was a popular anti-Catholic idea in society seeing Church as a dangerous institution (Jenkins 1996, 2003).

In fact, most clergy sexual abuse cases came from the 1980s and 1990s of the 20th century, while since then, the numbers have been lowering (Terry et al. 2011). According to Terry's finding, priests ordained in years 1960-1975 were disproportionately more likely to abuse children than those ordained before and after that period. The reason for this disproportion lies in a higher demand for priests in the period, thus resulting in a lowering of the requirements in the seminaries and an acceptance of immature candidates (Terry et al. 2011).

Regardless of all the possible roots, even worse thanthe problem of clergy sexual abuse is its long-lasting silencing and covering up from the side of the bishops. It is ironic that the Greek verb episkopein from which episcopus (bishop) is derived means "to keep watch". Since Boston's causes, Pope John Paul II (BBC 2002) and after him Benedict XVI (Nasaw and Butt 2008) had to cope administratively and medially with these sad facts. Benedict XVI was the first pontiff who apologized to the victims and received them personally in 2001 during his visit to the USA, which was the most mediatized occasion until 2015, when Pope Francis visited (Gaitano 2016). In the administrative sense, Francis instituted The Pontifical Commission for the Protection of Minors within the Roman Curia in 2014 to control the safeguarding. In addition, in 2012, The Centre for Child Protection was established by the Pontifical Gregorian University with collaborating universities throughout the world. This centre enables studying the prevention of clergy sexual abuse, coordinates conferences, and publishes articles from a wide range of fields.

Nevertheless, the task to communicate the abuse crisis is naturally a great challenge for the Vatican spokesmen.

\section{Catholic Church in the "Wicked Crisis"}

The Catholic Church always showed its genius ability to adapt to new conditions and to survive. It is the "wealthiest" and the "oldest" institution in the world (Farrell 2009, p. 44). Although the Church has already performed some interventions in dealing with the abuse crisis and aims to prevent future disasters (Meeting on The Protection of Minors in the Church 2019), it has yet to recover from the damage done to its reputation, identity, and image. 
Theoretically, the organizational crisis can be defined as a specific, unexpected, and non-routine event (or series of events) that creates high levels of uncertainty and threatens or can put an organization's high priority goals at risk, attacking the organisation's reputation and legitimacy;however, it can also be perceived as an "opportunity" (Ulmer et al. 2011, p. 7). Similarly, with inappropriate communication it can even lead to the weakening and loss of self-confidence forever (Ulmer et al. 2011, p. 4). Furthermore, the crisis differs from other unpleasant occasions experienced by organisations because there is usually a short response time (Hermann 1963). According to Ulmer's typology, in the case of the Church, we are very close to this concept of crisis caused by unethical behaviour, sabotage, or work-place violence.

An alternative approach towards the Catholic Church crisis was developed in a recent study (Maier and Crist 2017). It specifically targets the US situation but may be applied generally. This approach elaborates upon the thoughts of French Catholic phenomenologist Jean-Luc Marion (1998, 2002a, 2002b, 2008) who introduced the idea of responsible witness (resp. "response-able" in Marion's interpretation, thus able to respond) as the means of dealing with the wicked crisis - a concept already established in the area of crisis communication (Rittell and Webber 1973). In addition to this, in Marion's interpretation, the term wicked crisis refers to the fact that some types of crises are overwhelming us with their wickedness and leaving us bedazzled when seeing too much. This position of ethical responsibility and individual response (Fink 1986) is strongly articulated in Marion's philosophy, which calls us not simply to deal with the crisis, as our instinct calls, but to let ourselves be awakened by the unspeakable trauma of abuse and to constantly expand our sense of urgency: " . . . to feel [ourselves] called and held at a distance by the weight of an invisible look, by its silent appeal" (Marion 2002b, p. 119). This approach puts emphasis not on the application of the theories or tactics but concentrates on how to be in a crisis (Budd and Velasquez 2014).

Marion's approach consists-contrary to all crisis communication advice-of the risk to be wounded and even totally broken, to sacrifice the reputation, well-being, and status quo of an institution. Therefore, such proceeding needs a "different type of crisis leadership" (Alpaslan and Mitroff 2011, p. 166). These authors even made a typology of the phenomenon that complicates uncovering, confronting, and finally stopping the huge crisis or mess. This is because such a mess is a combination or system of swans (false assumptions and mistaken beliefs), swine (greed, hubris, arrogance, and narcissism), and swindlers (unethical and corrupt behaviour). Therefore, such a deep crisis must be "managed as such" (with all three components), or it cannot be managed at all (Alpaslan and Mitroff 2011, p. 171).

Earlier, an especially challenging critique of the concept of wicked crisis emerged in works concerning the influence of the correct understanding of crisis itself in order to know how to practise crisis communication (Grint 2010). According to Grint, wicked problems require the "transfer of authority from individual to collective" (Grint 2010, p. 308). Therefore, the role of the leader is to learn the collective in order to face these problems, not to deal them heroically, alone.

Authors Maier and Crist (2017) labelled the US clergy sexual abuse crisis as such a wicked crisis, the worst in the religious history of the US. As a solution, they suggest lettingthe crisis itself talk-“"articulate, with brutal clarity, what has occurred, why it occurred, why it is still occurring" (Maier and Crist 2017, p. 171) —and to "make a shift from preservation toward reconciliation" (Maier and Crist 2017, p. 172).

Situations such as this abuse crisis are, according to other interpretations, even comparable to a biblical skandalon or "stumbling block", tempting another to sin or destruct (Lev 19:14, Psalm 140:9, Matthew 13:41-and other 14 times in New Testament), elsewhere called a snare (Arendt 2003), showing much more than a problem to deal with-showing, instead, the banality of evil (Arendt 2006). Therefore, a significant problem with a crisis characterized as wicked is that it is presumably immune towards the handling (Rittell and Webber 1973), because it makes the efforts of the communicating agent-independent of 
whether it is in the form of an apology, the aims to minimize crisis, or pleas for sympathy, etc.-almost impossible.

\section{Methodology and Research Questions}

Having presented the theoretical background of Vatican media communication throughout history, we can make a small investigation into Matteo Bruni's journalistic output. The aim of this piece is to inquire into the background of the introduced facts and concepts concerning the ways that the character of Vatican communication changed from Bruni's appointment in July 2019 to 25 November 2019.

The source of data for the combination of quantitative and qualitative analysis of media content were taken from texts published on the Vatican News website (English version). Therefore, the articles were coded according to the occurrence of the keyword "Bruni". Four categories were proposed: (1) thematic section of Vatican News (Pope, Vatican, Church, World), (2) type of quotation (directly, indirectly, only his name in the text), (3) topic of the quote (Congratulation to Murray, Benedict XVI, Senez's book, PanAmazonian synod, Vatican Financial Authority, cause of Cardinal George Pell, VaticanChina relations, Vietnam-China relations, condolence for the death of Cardinal Etchegaray, Francis's personal secretary change), and (4) who is in the photo (Bruni with Pope, Murray, Benedict XVI, Pope with Imam, Pope in Africa, Pan-Amazonian Synod, Chinese Catholics, Chinese bishop, Francis's former secretary, church, illustrative picture).

\section{Outcomes}

In this small inquiry, we found astonishingly little. We realized that Bruni's media communication had no depth or journalistic character, and that it is profiled diplomatically rather than journalistically. There were altogether 17 pieces of English-written content published in Vatican News and related to the activity of Matteo Bruni between 18July and 25 November 2019. The average frequency of the content is $2-5$ times per month. The prevailing proportion (nine) was found in the thematic section Pope, then five in the section Vatican, and three in the section Church. In the prevailing part, Bruni was quoted directly (11); in four items, he was not quoted at all; and in two, he was quoted only indirectly.

There were only two news items found which consider the sexual abuse crisis with reference to the trial of Cardinal George Pell (see the detailed elaboration further), and in these cases, Pell was also in the picture. In the first, Bruni assures readers that the Vatican is "awaiting the outcome" of the court, and it already "confirmed the precautionary measures" which meant for Pell "the prohibition from exercising public ministry and from any voluntary contact whatsoever with minors" (Vatican News 2019e). In the second news item following the court's decision to uphold Pell's convictions, Bruni simply restated what he had said before (Vatican News 2019e). Among the other pictures related, there were two of Bruni with the pope, three of the popeon other occasions, and two of Benedict XVI.

The preceding questions cannot be answered positively because it is impossible to perform any evaluation with such few data. The outcomes are surely very surprising with the brevity of all the content. We can only guess which approach or conviction Bruni maintains in the credibility crisis: if he supports the aims of Pope Francis or if he is able to address people outside of the Catholic Church, too. In the following, the data will be viewed from a more detailed point of view:

The first news item was published on 18 July and simply reports on the fact of Bruni's appointment taking place on 22 July (Vatican News 2019d; Pope Makes Appointments in Vatican Media 2019). It was a more complex change because the former spokesman Alessandro Gisotti was moved to the position of deputy director of the editorial direction at the Dicastery for Communication together with Sergio Centofanti. In the photo, we can see Bruni smiling together with the pope during a visit to Romania.

Then, there was Bruni's quotation a few days later, when he congratulated the newly appointed Brazilian-born journalist Christiane Murray to the position of his deputy director: "The experience she has gained in years of service to the Church and to the Holy See are 
extremely valuable assets for this new position" (Bordoni 2019). Later, Bruni was also indirectly quoted in the text about Pope Emeritus Benedict XVI's visit to Castel Gandolfo (Watkins 2019a).

The first exceptional moment for the new Vatican spokesman came in August, when he responded to journalistic questions about the dismissal of Cardinal George Pell's appeal by The Supreme Court in Australian Victoria: "As in other cases, the Congregation for the Doctrine of the Faith is awaiting the outcome of the ongoing proceedings and the conclusion of the appellate process prior to taking up the case. As was stated by the Holy See Press Office on 26 February, the Holy Father had already confirmed the precautionary measures imposed on Cardinal Pell upon his return to Australia, that is, as is the norm, the prohibition from exercising public ministry and from any voluntary contact whatsoever with minors" (Vatican News 2019e).

Bilateral relationships were a theme of the content connected with Bruni's name, when the Vietnamese delegation visited the Vatican for the occasion of theeighth meeting of The Socialist Republic of Vietnam and Holy See Joint Working Group. "The meeting is intended to develop and advance bilateral relations, focusing in particular on some aspects of the ecclesial life of the country as well as issues regarding the status and mission of the resident Papal Representative in Viet Nam and the visit of His Eminence Cardinal Secretary of State Pietro Parolin, to take place in the near future", said a press statement by Bruni (Vatican News 2019g).

In August, Bruni announced Francis's appreciation of a new committee set up in the United Arab Emirates to promote the ideals contained in the Document on Human Fraternity signed by the pope and the Grand Imam of Al-Azhar, Ahmed el-Tayyeb, in Abu Dhabi in February 2019 (Watkins 2019b).

The end of August was dominated by news about the consecration of the first Chinese bishop, Antonio Yao Shun, following the Provisional Agreement between the Vatican and China (Donnini 2019). Additionally, the second bishop, Stefano Xu Hongwei, was consecrated soon after in September (Vatican News 2019f).

Another remarkable situation for Bruni's action came again in September during the pope's flight to an apostolic journey in Africa. A spokesman had to discuss the pope'sreception of the new book by Nicolas Senèze, reporter for La Croix, entitled How America Wants to Change the Pope, which sums up the US critique towards the contemporary pontificate. Originally, the pope said, when he first looked at the book, "This is a bomb!" (O'Connell 2019). According to Bruni's later correction, the pope said it in an informal context and wished to say that criticisms, for him, are "always an honour, particularly when they come from knowledgeable thinkers, and in this case from an important nation" (De Carolis 2019).

In the Mozambique capital, Maputo, the pope later spontaneously met with members of the Scholas Occurrentes foundation, which was simply announced by Bruni (Watkins 2019c). As the French Cardinal Roger Etchegaray, President emeritus of the Vatican's Pontifical Councils for Justice and Peace and of the Pontifical Council Cor Unum, died at the age of 96, the pope's prayers were with him even in Africa. According to Bruni, he learned about the fact "with pain"during mass in Maputo and recalled the Cardinal as a "man of dialogue and peace" (Gomes 2019).

The case of Cardinal George Pell came back in September with his final appeal against sexual abuse convictions. Following the court's decision to uphold his convictions, Bruni reacted: "As in other cases, the Congregation for the Doctrine of the Faith is awaiting the outcome of the ongoing proceedings and the conclusion of the appellate process prior to taking up the case ... As was stated by the Holy See Press Office on 26 February, the Holy Father had already confirmed the precautionary measures imposed on Cardinal Pell upon his return to Australia, that is, as is the norm, the prohibition from exercising public ministry and from any voluntary contact whatsoever with minors" (Vatican News 2019e).

After creating 13 new cardinals from all over the world at the beginning of October, they met with Pope Francis and Pope Emeritus Benedict XVI in the Mater Ecclesiae 
Monastery. Therefore, Bruni issued an official statement for journalists: “ . . after a brief greeting, in which he [Benedict XVI] reminded the new cardinals of the value of fidelity to the pope, Benedict XVI, together with Pope Francis, gave them a blessing ... " (Vatican News 2019h).

Then, Bruni was mentioned in an article related to the Pan-Amazonian synod in the Vatican as the member of the Information Committee (Vatican News 2019a). On this important three-week-long occasion, Bruni was quoted directly when the pope met with Indigenous people: "They expressed their gratitude to the Holy Father for convoking the Synod, and asked for help in implementing their desire to ensure a peaceful and happy life for their peoples, caring for their land, and protecting its waters, for their descendants to enjoy" (Vatican News 2019b). Then, he added words about the pope's address and "pointing out the dangers of new forms of colonization" (Vatican News 2019b).

In November, the next quotation followed with reference to personnel changes in the Vatican Financial Authority. Bruni announced that the deferral of the appointment of the new president was necessarily made in order to allow "the interested party to respect previous institutional commitments, and for the definition of some internal procedures of the Holy See" (Vatican News 2019c).

The very last news item in this limited period of time was commentary on the fact that Pope Francis's personal secretary, Fabián PedacchioLeániz, would leave his position as part of an "ordinary rotation of functions", which was decided "some time ago", after six years of service. Bruni addedthatPedacchio, together with the second personal secretary of the pope, the Egyptian priest YoannisLahziGaid, had taken up the position "in addition to their previous functions, to which they might return, full time" (Vatican News 2019i).

\section{Conclusions}

May the Vatican spokesman have the courage to lose his "bellafigura" in order to stay close to the victims of clergy sexual abuse and move Vatican communication towards accountability and credibility_inspired by Marion's vision of responsible witness? From the newscast monitoring, it seems that Matteo Bruni is more occupied with diplomatic issues than with the clear communication of abuse in Church. Generally, the early activities of Bruni in the position of Vatican spokesman seem to make a rather tentative impression and, in the prevailing part of the cases, say nothing about one of the key themes of today's Catholic Church. Seventeen media items related explicitly with his name can be considered as the scatter. Furthermore, there is-with the exception of rather "technical" statements on Cardinal Pell's case-disinterest in the profound communication of the abuse of power, conscience, and the sexual abuse of minors and vulnerable adults in the Church. Additionally, it is quite significant that, after four months in the service of Vatican Press Office Spokesman, there is almost no information accessible about him when we try to search on the Internet, except for the announcementthat he was appointed to the position. He is even not active at all on social media sites. Basically, he has his accounts on Facebook and Twitter, but he does not use them as his colleagues from the dicastery do daily.

As noted previously, this is the first time in history that the status of the Vatican spokesman has not been that of a journalist. Since the beginning of his service, some media have already questioned his capability to improve the role of the Press Office. They even ironically compared Bruni to the former spokesman of St. John Paul II, Joaquin Navarro Valls, who had shaped the image of pope and the Vatican for a period of 22 years and, coincidentally, was also a member of the spiritual movement close to the pope's heart (Opus Dei). Similarly, Bruni is a member of Sant' Egidio, which takes care of poor or migrant people, to which Francis is sympathetic (Allen 2019). It is not at all clear whether Bruni will be able to wield the same influence as Navarro Valls, in part because Pope Francis seems not to take the corporate communications or the role of his spokesman "especially seriously" and instead he usually acts as "his own spokesman", which surprised even his previous three spokesmen-F. Federico Lombardi (2013-2016), Greg Burke (2016-2018) and Alessandro Gisotti (interim, 2019), as Allen argues (2019). Nevertheless, when we compare 
Bruni to Gisotti, the latter was doing a good job for 7 months of an unexpected job filled with a number of affairs of clerics, the important Vatican summit "The Protection of Minors in the Church", and eight papal trips creating a certain communication risk.

Pope John Paul II recognized that media were able to change the world not by their technological means but because of the communicated content, and he knew thatthis is more than good PR for the Church. Furthermore, in the 3rd millennium, the hierarchical relationships between "leaders" and "followers" are no longer sustainable. Pope Francis, one of the most influential leaders of our time, seems to prefer to execute some parts of the Vatican communication on his own. At the same, the role of Vatican spokesman-once key to understanding the papacy-is weakening. The future challenge for improvement seems to grow from the consciousness of authority and its possible transfer from an individual to collective one, thus leading to some decentralization and withdrawal from the "heroic" style of communication.

Funding: This research received no external funding.

Institutional Review Board Statement: Not applicable.

Informed Consent Statement: Not applicable.

Data Availability Statement: Not applicable.

Conflicts of Interest: The author declares no conflict of interest.

\section{References}

About Us. 2019. Vatican News. Available online: https:/ / www.vaticannews.va/en/about-us.html (accessed on 29 November 2019). Aetatis Novae. 1992. Aetatis Novae: On Social Communications on the Twentieth Anniversary of Communio et Progression. Pastoral Instruction. Vatican.va. Available online: http://www.vatican.va/roman_curia/pontifical_councils/pccs/documents/rc_pc_ pccs_doc_22021992_aetatis_en.html (accessed on 29 November 2019).

Allen, John, Jr. 2019. As a pope PICKS a spokesman, could history repeat itself? Crux Now, July 19. Available online: https: //cruxnow.com/news-analysis/2019/07/as-a-pope-picks-a-spokesman-could-history-repeat-itself/ (accessed on 29 November 2019).

Allen, John, Jr., and InésSan Martín. 2017. Church Communications Highlights 2016. Church Communications and Culture 2: 8-24. [CrossRef]

Alpaslan, Can, and Ian Mitroff. 2011. Swans, Swine, and Swindlers: Coping with the Growing Threat of Mega-Crises and Mega-Messes. Stanford: Stanford Business Books, ISBN 978-0804771375.

Althoff, Gerd, Fonnesberg-Schmidt Iben, and Kynan-Wilson William. 2018. Framing papal communication in the central Middle Ages. Journal of Medieval History 44: 251-60. [CrossRef]

Altieri, Christopher. 2019. For the First Time, a non-journalist is Director of the Vatican Press Office. Catholic Herald, July 19. Available online: https:/ / catholicherald.co.uk/commentandblogs/2019/07/19/for-the-first-time-a-non-journalist-is-directorof-the-vatican-press-office/ (accessed on 29 November 2019).

Amundson, Jon, Kenneth Stewart, and LaNae Valentine. 1993. Temptations of power and certainty. Journal of Marital and Family Therapy 19: 111-23. [CrossRef]

Arendt, Hannah. 2003. Some Questions of Moral Philosophy. In Responsibility and Judgment. Edited by Jerome Kohn. New York: Schocken, pp. 49-146. ISBN 978-0805211627.

Arendt, Hannah. 2006. Eichmann in Jerusalem: A Report on the Banality of Evil. New York: Penguin, ISBN 978-0143039884.

Bass, Bernard, and Bruce Avolio. 1994. Improving Organizational Effectiveness through Transformational Leadership. Thousand Oaks: Sage.

BBC. 2002. Pope Denounces 'Evil' Sex Priests. BBC, March 21. Available online: http://news.bbc.co.uk/2/hi/europe/1885380.stm (accessed on 29 November 2019).

Benedict XVI. 2013. Message for the 47th World Communications Day. Social Networks: Portals of Truth and Faith; New Spaces for Evangelization. Vatican. va. Available online: https://www.vatican.va/content/benedict-xvi/en/messages/communications/ documents/hf_ben-xvi_mes_20130124_47th-world-communications-day.html (accessed on 1 July 2021).

Berry, Jason. 2002. Lead Us Not into Temptation: Catholic priests and the Sexual Abuse of Children. New York: Doubleday, ISBN 978-1482568905.

Bordoni, Linda. 2018. Pope Makes New Appointments at Vatican Media. Comunicazione.va, December 18. Available online: http:/ / www.comunicazione.va/en/notizie/notizie-2018/pope-makes-new-appointments-at-vatican-media.html (accessed on 29 November 2019).

Bordoni, Linda. 2019. Pope Appoints Vatican News Journalist as Deputy Director of Press Office. Vatican News, July 25. Available online: https:/ / www.vaticannews.va/en/pope/news/2019-07/pope-cristiane-murray-holy-see-press-office-deputy-director. html (accessed on 29 November 2019). 
Borg, Joseph. 2015. Communicating Faith through the Legacy Media. Theological Reflections and Pastoral Implication. KulturaMedia-Teologia 20: 9-24.

Boston Globe. 2002. Betrayal: The Crisis in the Catholic Church. Boston: Little, Brown.

Budd, John, and Diane Velasquez. 2014. Phenomenology and organizational communication. New Library World 115: $394-404$. [CrossRef]

Burkett, Elinor, and Frank Bruni. 1993. A Gospel of Shame: Children, Sexual Abuse, and the Catholic Church. New York: Harper Perennial, ISBN 978-0670848287.

Caccamo, James. 2008. The Message on the Media: Seventy Years of Catholic Social Teaching on Social Communication. JosephinumJournal of Theology 15: 390-426.

Campbell, H. 2010. A When Religion Meets New Media. New York: Routledge.

Campbell, Heidi. 2014. Digital Religion Understanding Religious Practice in New Media Worlds. London: Routledge, ISBN 9780415676113.

Carroll, Pfeiffer, and Robinson Rezendes. 2002. Church Allowed abuse by Priest for Years. Boston Globe, February 9. Available online: https:/ / www.bostonglobe.com/news/special-reports/2002/01/06/church-allowed-abuse-priest-for-years/cSHfGkTIrAT2 $5 q K G v B u D N M /$ story.html (accessed on 29 November 2019).

Catechism of Catholic Church. 1993. Vatican.va. Available online: http://www.vatican.va/archive/ENG0015/_INDEX.HTM (accessed on 29 November 2019).

Cha, Meeyoung, Hamed Haddadi, Fabricio Benevenuto, and Krishna Gummadi. 2010. Measuring user influence in Twitter: The million followers fallacy. Paper presented at the 4th International AAAI Conference on Weblogs and Social Media, Washington, DC, USA, May 23-26.

Code of Canon Law. 1983. Vatican.va. Available online: http://www.vatican.va/archive/cod-iuris-canonici/cic_index_en.html (accessed on 29 November 2019).

Communio et Progressio. 1971. On the Means of Social Communication. Pastoral Instruction. Vatican.va. Available online: http: //www.vatican.va/roman_curia/pontifical_councils/pccs/documents/rc_pc_pccs_doc_23051971_communio_en.html (accessed on 29 November 2019).

D'Ancona, Matthew. 2017. Post-Truth: The New War on Truth and How to Fight Back. London: Ebury Press, ISBN 978-1785036873.

De Carolis, Alessandro. 2019. Journalists Joke with Pope about Being Stuck in the Elevator. Vatican News, September 4. Available online: https:/ / www.vaticannews.va/en/pope/news/2019-09/pope-francis-mozambique-departure-rome0.html (accessed on 29 November 2019).

Diez Bosch, Miriam. 2018. The Vaticanologists: Covering the Holy See. In Spiritual News. Reporting Religion Around the World. Edited by Yoel Cohen. Bern: Peter Lang, ISBN 978-1-4331-4534-6.

Donnini, Debora. 2019. China, Consecration of First Bishop Following Provisional Agreement. Vatican Nerws, August 28. Available online: https:/ / www.vaticannews.va/en/church/news/2019-08/china-consecration-of-first-bishop-following-provisionalagreem.html (accessed on 29 November 2019).

Farrell, Derek P. 2009. Sexual abuse perpetrated by Roman Catholic priests and religious. Mental Health, Religion E Culture 12: 39-53. [CrossRef]

Fink, Steven. 1986. Crisis Management: Planning for the Inevitable. New York: American Management Association, ISBN 0814458599.

Gaitano, Norberto González. 2016. Public opinion in the Church. A communicative and ecclesiological reflection. Church, Communication and Culture 1: 173-205. [CrossRef]

Gesiak, Leszek. 2017. Reform of the Vatican media, a difficult search for a new path. The Person and the Challenges. The Journal of Theology, Education, Canon Law and Social Studies Inspired by Pope John Paul II 7: 5. [CrossRef]

Giovagnoli, Agostino. 2019. Pope Francis: A new way of looking at the world. Journal of Modern Italian Studies 24: 456-67. [CrossRef]

Gomes, Robin. 2019. French Cardinal Etchegaray dies. Pope Francis: A man of dialogue. Vatican News, September 5. Available online: https: / / www.vaticannews.va/en/vatican-city/news/2019-09/cardinal-etchegaray-dead-france.html (accessed on 29 November 2019).

Grint, Keith. 2010. The cuckoo clock syndrome: Addicted to command, allergic to leadership. European Management Journal 28: 306-13. [CrossRef]

Hermann, Charles F. 1963. Some consequences of crisis which limit the viability of the organisations. Administrative Science Quarterly 8: 61-82. [CrossRef]

Inter Mirifica. 1963. Vatican.va. Available online: http://www.vatican.va/archive/hist_councils/ii_vatican_council/documents/vatii_decree_19631204_inter-mirifica_en.html (accessed on 29 November 2019).

Javier Pérez-Latre, Francisco. 2019. Los medios, los papas y la comunicación del Vaticano entre Benedicto XVI y Francisco (2007-2017). Church, Communication and Culture 4: 61-78. [CrossRef]

Jenkins, P. 1996. Paedophiles and Priests. New York: Oxford University Press, ISBN 978-0195145977.

Jenkins, P. 2003. The New Anti-Catholicism: The Last Acceptable Prejudice. Oxford: Oxford University Press, ISBN 978-0195176049.

John Paul II. 1990. RedemptorisMissio. Encyclical letter. Vatican.va, December 7. Available online: http:/ /www.vatican.va/content/ john-paul-ii/en/encyclicals/documents/hf_jp-ii_enc_07121990_redemptoris-missio.html (accessed on 29 November 2019).

John Paul II. 1992. PastoresDabo Vobis. Post-Synodal Apostolic Exhortation. Vatican.va, March 25. Available online: http://www. vatican.va/content/john-paul-ii/en/apost_exhortations/documents/hf_jp-ii_exh_25031992_pastores-dabo-vobis.html (accessed on 29 November 2019). 
John Paul II. 2005. The Rapid Development: Apostolic Letter to Those Responsible for Social Communications. Available online: http: //www.vatican.va/holy_father/john_paul_ii/apost_letters/documents/hf_jp-ii_apl_20050124_il-rapido-sviluppo_en.Html (accessed on 29 November 2019).

Kappeler, Warren. 2006. Communication Habits for the Pilgrim Church: Vatican Teaching on Media and Social Communication. Ph.D. thesis, Faculty of Religious Studies McGill University, Montreal, QC, Canada.

La Curia Romana. 2019. Vatican.va. Available online: http://w2.vatican.va/content/romancuria/it.html (accessed on 29 November 2019).

López, María-Paz. 2019. Church communication highlights 2018. Church, Communication and Culture 4: 5-24. [CrossRef]

Lundgren, Kari. 2017. The paradox of the "people's pope": Pope Francis and the cult of authenticity. International Journal of Media $\mathcal{E}$ Cultural Politics 13: 303-12. [CrossRef]

Maier, Craig, and Jonathan R. Crist. 2017. From “Wicked Crisis” to Responsive Witness: Jean-Luc Marion and the American Roman Catholic Sexual-Abuse Scandal. Southern Communication Journal 82: 164-74. [CrossRef]

Marion, Jean-Luc. 1998. Reduction and Givenness: Investigations of Husserl, Heidegger and Phenomenology. Translated by Thomas Carlson. Evanston: Northwestern University Press.

Marion, Jean-Luc. 2002a. Being Given: Toward a Phenomenology of Givenness. Stanford: Stanford University Press.

Marion, Jean-Luc. 2002b. In Excess: Studies in Saturated Phenomena. Translated by R. Horner, and V. Berraud. New York: Fordham University Press.

Marion, Jean-Luc. 2008. The banality of saturation. In The Visible and the Revealed. Translated by C. M. Gschwandtner. New York: Fordham University Press, pp. 119-44.

Mintzberg, Henry. 2010. Il Lavoro Manageriale. Milan: Franco Angeli.

Narbona, Juan. 2016. Digital Leadership, Twitter and Pope Francis. Church, Communication and Culture 1: 90-109. [CrossRef]

Nasaw, Daniel, and Riazat Butt. 2008. Pope 'deeply ashamed' of child abuse scandals. The Guardian, April 15. Available online: https:/ / www.theguardian.com/world/2008/apr/15/religion.usa (accessed on 29 November 2019).

Northouse, Peter. 2013. Leadership: Theory and Practice, 6th ed. Thousand Oaks: SAGE.

O'Connell, Gerard. 2019. Pope Francis to Journalist: 'I am Honoured that the Americans Attack Me'. America Magazine, September 4. Available online: https:/ /www.americamagazine.org/faith/2019/09/04/pope-francis-journalist-i-am-honored-americansattack-me (accessed on 29 November 2019).

Palakeel, Joseph Scaria. 2019. Kairos of mercy and rhetoric of conversion. Church, Communication and Culture 4: 248-50. [CrossRef]

Pastor Aeternus. 1870. Dogmatic Constitution on the Church of Christ [online]. Available online: http://w2.vatican.va/content/ vatican/it.html (accessed on 11 July 2021).

Petráček, Tomáš. 2013. Sekularizace a katolicismus v českých zemích. [Secularisation and Catholicism in the Czech lands]. Ostrava: Moravapress, ISBN 978-80-87853-05-4.

Podles, Leon J. 2008. Sacrilege: Sexual Abuse in the Catholic Church. Columbus: Crossland Press, ISBN 978-0979027994.

Pope Francis. 2015. Motu proprio: For the establishment of the Secretariat for Communication. Vatican.va, June 27. Available online: https:/ /w2.vatican.va/content/francesco/en/motu_proprio/documents/papa-francesco-motu-proprio_201506 27_segreteria-comunicazione.html (accessed on 29 November 2019).

Pope Francis. 2017. Address of Pope Francis to the Plenary Assembly of the Secretariat for Communication. Vatican.va, May 4. Available online: https://w2.vatican.va/content/francesco/en/speeches/2017/may/documents/papa-francesco_20170504 _plenaria-segreteria-comunicazione.html (accessed on 29 November 2019).

Pope Francis. 2018. Rescriptum ex Audientia. Summary of Bulletin. Vatican.va, June 23. Available online: http:/ / press.vatican.va/ content/salastampa/en/bollettino/pubblico/2018/06/23/180623f.html (accessed on 29 November 2019).

Pope Makes Appointments in Vatican Media. 2019. Comunicazione.va, July 18. Available online: http:/ / www.comunicazione.va/en/ notizie/notizie-2019/pope-makes-appointments-in-vatican-media.html (accessed on 29 November 2019).

Pope Pius X. 1907. Pascendi Dominici Gregis. Encyclical on the Doctrines of ohe Modernists. Vatican va, September 8. Available online: http:/ / www.vatican.va/content/pius-x/en/encyclicals /documents/hf_p-x_enc_19070908_pascendi-dominici-gregis html (accessed on 29 November 2019).

Rittell, Horst, and Melvin Webber. 1973. Dilemmas in a general theory of planning. Policy Sciences 4: 155-69. [CrossRef]

San Martín, Inés. 2019. British-born Italian layman appointed new Vatican spokesperson. Crux Now, July 18. Available online: https:// cruxnow.com/vatican/2019/07/british-born-italian-layman-appointed-new-vatican-spokesperson/ (accessed on 29 November 2019).

Scharer, Matthias, and Bernd Jochen Hilberath. 2008. The Practice of Communicative Theology. New York: Crossroad.

Sipe, Richard. 1995. Sex, Priests, and Power-Anatomy of Crisis. London: Cassell.

Spadaro, Antonio. 2014. Cybertheology: Thinking Christianity in the Era of the Internet. New York: Fordham University Press, ISBN 978-0-8232-5700-3.

Terry, Karen J., Margaret Leland Smith, Katrina Schuth, James R. Kelly, Brenda Vollman, and Christina Massey. 2011. The Causes and Context of Sexual Abuse of Minors by Catholic Priests in the United States, 1950-2010. Washington, DC: United States Conference of Catholic Bishops.

The Protection of Minors in the Church. 2019. PBC Meeting held on 21-24 February 2019. PBC. Available online: https://www.pbc201 9.org/home (accessed on 29 November 2019). 
Ulmer, Robert R., Timothy L. Sellnow, and Matthew W. Seeger. 2011. Effective Crisis Communication: Moving from Crisis to Opportunity, 2nd ed. Thousand Oaks: Sage.

Václavík, David. 2010. Náboženství a moderníčeskáspolečnost. [The Religion and the Modern Czech Society]. Praha: Grada, ISBN 978-80-2472468-3.

Vatican News. 2018a. Pope names new Prefect for Dicastery for Communication. Comunicazione.va, July 5. Available online: http: //www.comunicazione.va/en/notizie/notizie-2018/pope-names-new-prefect-for-dicastery-for-communication.html (accessed on 29 November 2019).

Vatican News. 2018b. Vatican's Prefect for Communication resigns. Vatican News, March 21. Available online: https://www. vaticannews.va/en/vatican-city/news/2018-03/vatican-prefect-communication-resigns-.html (accessed on 29 November 2019).

Vatican News. 2019a. \#AmazonSynod. Young people, protagonists of integral ecology. Vatican News, October 8. Available online: https: //www.vaticannews.va/en/pope/news/2019-10/amazonsynod-young-people-protagonists-of-integral-ecology.html (accessed on 29 November 2019).

Vatican News. 2019b. Synod for the Amazon: Pope meets with group of indigenous people. Vatican News, October 18. Available online: https:/ / www.vaticannews.va/en/pope/news/2019-10/synod-for-the-amazon-pope-meets-with-group-of-indigenouspeople.html (accessed on 29 November 2019).

Vatican News. 2019c. Pope appoints new President of Vatican Financial Authority. Vatican News, November 18. Available online: https: //www.vaticannews.va/en/pope/news/2019-11/vatican-financial-authority-pope-rene-bruelhart-new-appointment.html (accessed on 29 November 2019).

Vatican News. 2019d. A Brief Outline and History of the Pontifical Council for Social Communications. Vatican.va. Available online: http:/ / www.vatican.va/roman_curia/pontifical_councils / pccs/documents/rc_pc_pccs_pro_14101999_en.html (accessed on 29 November 2019).

Vatican News. 2019e. Australian Court Dismisses Cardinal Pell's Appeal. Vatican News, August 20. Available online: https: / / www.vaticannews.va/en/church/news/2019-08/australia-cardinal-pell-appeal-decision.html (accessed on 29 November 2019).

Vatican News. 2019f. China, Second Bishop Consecrated under Sino-Holy See Agreement. Vatican News, August 28. Available online: https: / / www.vaticannews.va/en/church/news/2019-08/china-second-bishop-provisional-agreement-xu.html (accessed on 29 November 2019).

Vatican News. 2019g. Holy See-Vietnam Talks in the Vatican. Vatican News, August 20. Available online: https://www.vaticannews. va/en/vatican-city/news/2019-08/holy-see-vietnam-joint-working-group-vatican.html (accessed on 29 November 2019).

Vatican News. 2019h. Pope emeritus to new Cardinals: Remember the value of fidelity to the Pope. Vatican News, October 5. Available online: https: / / www.vaticannews.va/en/vatican-city/news/2019-10/new-cardinals-visit-pope-emeritus.html (accessed on 29 November 2019).

Vatican News. 2019i. Pope's personal secretary to leave his position. Vatican News, November 25. Available online: https:// www.vaticannews.va/en/vatican-city/news/2019-11/pope-francis-personal-secretary-to-leave-position.html (accessed on 29 November 2019).

Watkins, Devin. 2019a. Pope emeritus Benedict XVI visits papal summer residence near Rome. Vatican News, July 26. Available online: https: / / www.vaticannews.va/en/pope/news/2019-07/pope-emeritus-benedict-xvi-summer-residence-visit-castelli. html (accessed on 29 November 2019).

Watkins, Devin. 2019b. Pope welcomes new UAE committee to promote Human Fraternity. Vatican Nerws, August 26. Available online: https:/ / www.vaticannews.va/en/pope/news/2019-08/pope-francis-welcomes-uae-fraternity-committee.html (accessed on 29 November 2019).

Watkins, Devin. 2019c. Pope recalls playing soccer with homemade ball as child. Vatican News, September 5. Available online: https: / / www.vaticannews.va/en/pope/news/2019-09/pope-francis-meets-scholas-occurrentes-mozambique.html (accessed on 29 November 2019).

Weber, Max. 1978. Economy and Society: An Outline of Interpretive Sociology. Berkeley: University of California Press, vol. 1. 